\title{
Effect of previous soil management on sugarcane response to nitrogen
} fertilization

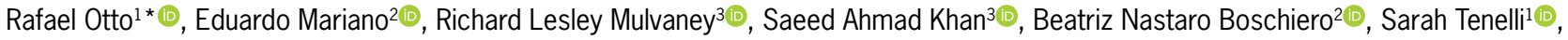 \\ Paulo Cezar Ocheuze Trivelin²
}

IUniversidade de São Paulo/ESALQ - Depto. de Ciência do Solo, Av. Pádua Dias, 11 - 13418-900 - Piracicaba, SP Brasil.

2Universidade de São Paulo/CENA - Lab. de Isótopos Estáveis, Av. Centenário, 303 -13416-000 - Piracicaba, $\mathrm{SP}$ - Brasil.

${ }^{3}$ University of Illinois - Dept. of Natural Resources and Environmental Sciences, 1102 S. Goodwin Av. - 61801 Urbana, IL - USA.

*Corresponding author <rotto@usp.br>

Edited by: Leônidas Carrijo Azevedo Melo

Received April 24, 2017

Accepted August 03, 2017
ABSTRACT: $\mathbf{N}$ Fertilizer recommendations must be improved to optimize $\mathrm{N}$ use efficiency (NUE) for bioenergy crops. A study was conducted to test the hypothesis that sites varying in historical usage of by-product differ in soil N-supplying power and sugarcane (Saccharum spp.) responsiveness to $\mathrm{N}$ fertilization. Our aim was to quantify soil $\mathrm{N}$ availability and $\mathrm{N}$ fertilizer rates, sources, and application timings for their effects on sugarcane yield and NUE. Three N response trials, each involving 0 to $200 \mathrm{~kg} \mathrm{~N} \mathrm{ha}^{-1}$, were conducted in the state of São Paulo, Brazil, at sites varying historically in the usage of vinasse. Before fertilizer application and at harvest, soil inorganic $\mathrm{N}$ content was quantified and potential $\mathrm{N}$ mineralization estimated by the llinois Soil Nitrogen Test (ISNT); stalk yield and sugar content were measured at harvest and used to estimate NUE. Sugarcane showed significant response to $N$ fertilization only at the sites with no history of vinasse usage. Reducing the $\mathrm{N}$ rate from 120 to $80 \mathrm{~kg} \mathrm{~N}$ ha-1 $^{-1}$ showed limited potential for lowering yield ( 1\%), while increasing the NUE by $54 \%$, which was far better than the 14 $\%$ increase achieved by modifying the $\mathrm{N}$ source or application timing. Monitoring inorganic $\mathrm{N}$ and ISNT levels over time to estimate soil $\mathrm{N}$-supplying power has potential for predicting the responsiveness of sugarcane to $\mathrm{N}$ fertilization; however, ISNT interpretations must consider factors that impede mineralization or crop $\mathrm{N}$ utilization, such as soil acidity or a limitation on the availability of $\mathrm{Ca}$ or $\mathrm{P}$. Soil $\mathrm{N}$ testing can help optimize NUE for sustainable bioenergy production. Keywords: Saccharum spp., Illinois Soil N Test, inorganic N, vinasse, mineralization

\section{Introduction}

Nitrogen use efficiency (NUE) has been studied extensively for cereal cropping (Raun and Johnson, 1999), but has not been a priority for sugarcane production (Zhao et al., 2014). This view is now changing in response to increasing concerns about the contribution of air and water pollution of excessive $\mathrm{N}$ fertilization, which has stimulated the emphasis of research on sugarcane (Saccharum spp.) NUE (Whan et al., 2010; Franco et al., 2011; Thorburn et al., 2011; Zhao et al., 2014). Progress in this direction could significantly reduce fertilizer costs and the release of $\mathrm{N}$ into the environment without negatively affecting yields (Hajaria et al., 2013).

Previous research on sugarcane indicates the potential for reducing $\mathrm{N}$ rates without sacrificing yield for sites with historical usage of by-products (Otto et al., 2013). One such by-product is vinasse, which is produced in conjunction with biomass distillation for the production of ethanol from sugar crops [sugar beet (Beta vulgaris L.) and sugarcane], starch crops [corn (Zea mays L.), wheat (Triticum aestivum L.), rice (Oriza sativa L.) and cassava (Manihot esculenta Crantz)], or cellulosic substrates such as crop residues, sugarcane bagasse, or wood (Christofoletti et al., 2013). Application of sugarcane vinasse causes a temporary increase in soil populations of fungi, actinomycetes, and cellulolytic bacteria (Santos et al., 2009), enhancing biomass C, N content and enzymatic activities (Yang et al., 2013) which, in turn, bring about an increase in plant growth due to greater nutrient release by microbial decomposition of organic substrates (Yang et al., 2013). The long-term impact for areas under vinasse application is an increase in soil content of organic C and N (Canellas et al., 2003), which would be expected to enhance soil $\mathrm{N}$ availability and thereby reduce the need for $\mathrm{N}$ fertilization.

Measurements of soil $\mathrm{N}$ supplying power is required to improve $\mathrm{N}$ recommendation systems that nowadays are based exclusively on the expected-yield concept (Spironello et al., 1997; Legendre et al., 2001; Schroeder et al., 2006). Monitoring inorganic soil N content in the field is an option for evaluating soil $\mathrm{N}$ supplying power (Bundy and Meisinger, 1994). Another possibility is to evaluate a soil hydrolysable $\mathrm{N}$ fraction estimated by the Illinois Soil Nitrogen Test (ISNT) which has been linked to reductions in responsiveness of grain crops (Khan et al., 2001; Roberts et al., 2013) or sugarcane (Otto et al., 2013) to N.

The present project was undertaken to better clarify how by-product usage affects $\mathrm{N}$ fertilizer requirement for sugarcane production. We hypothesized that for sites with a history of these inputs, an increase in soil $\mathrm{N}$ supplying power would limit the effectiveness of $\mathrm{N}$ fertilization for boosting stalk and sugar yield. Our aims were to (1) evaluate strategies for improving sugarcane NUE at sites with and without previous byproduct usage (by modifying rates, sources, or timing of $\mathrm{N}$ application); and (2) ascertain $\mathrm{N}$ responsiveness by measuring soil $\mathrm{N}$ availability. 


\section{Materials and Methods}

\section{Characterization of sites}

Three trials were conducted in sugarcane fields in the state of São Paulo, Brazil (Table 1). Two were initiated approximately $600 \mathrm{~m}$ from each other at Tabapuã, São Paulo on June 6, 2012, and another at Pereira Barreto, São Paulo on July 18, 2012. While Sites 1 and 2 have no historical use of by-products, Site 3 had annually received vinasse in the previous 5 years at a rate of $60 \mathrm{~m}^{3} \mathrm{ha}^{-1}$, the most recent application being made 2 weeks before this trial was initiated. The trials were all managed under the green cane system which involves mechanical harvesting without burning, and had received annual fertilizer inputs of N-P-K (Sites 1 and 2) or N-P (Site 3).

The soil at Site 1 corresponds to a Typic Hapludox, whereas the soil at Sites 2 and 3 were a Typic Kandiulstalf (Soil Survey Staff, 2014). To further characterize the soil physicochemical properties at each site (Table 2), profile sampling was performed prior to fertilization during field establishment, by excavating 12 holes to a depth of $1.0 \mathrm{~m}$ with a $10-\mathrm{cm}$ (diameter) auger at random locations within the experimental area, each approximately $25 \mathrm{~cm}$ from the nearest sugarcane row. The soil obtained was segregated by $0.2-\mathrm{m}$ depth intervals, giving five samples per site that were composited into polyethylene bags and then partitioned into two portions of similar weight, one for soil $\mathrm{N}$ analysis and the other for physicochemical characterization. Samples for $\mathrm{N}$ analysis were transferred to deep-freeze storage as soon as possible, while all others were oven-dried at $40{ }^{\circ} \mathrm{C}$ for $72 \mathrm{~h}$, followed by crushing with a mechanical grinder to $<2 \mathrm{~mm}$. Soil organic C (SOC) was estimated by dichromate oxidation using tube digestion (Nelson and Sommers, 1996), and total $\mathrm{N}$ by the regular Kjeldahl method (Bremner, 1996). Other chemical parameters followed Silva et al. (2009). Particle-size analyses were performed by the hydrometer method as described by Gee and Or (2002). Bulk density was determined in September 2012 for Sites 2 and 3 by the core method (Grossman and Reinsch, 2002), which involved collecting triplicate samples with a double-cylinder core sampler $(5$ $\mathrm{cm}$ diameter, $5 \mathrm{~cm}$ long) that was inserted into the wall exposed by auger excavation, at the midpoint of each $0.2-\mathrm{m}$ depth increment. The $98-\mathrm{cm}^{3}$ samples were obtained and then weighed after oven-drying at $105^{\circ} \mathrm{C}$ for $24 \mathrm{~h}$.

\section{Experimental design}

A randomized complete block design was utilized at each site, involving five repetitions of nine treatments that were randomly applied to plots comprising eight sugarcane rows spaced $1.5 \mathrm{~m}$ apart measuring $10 \mathrm{~m}$ in length. The treatments included a control without fertilizer $\mathrm{N}$ (T1);

Table 1 - Experimental locations and management summary.

\begin{tabular}{lccccc}
\hline Site & City & Location & Sugarcane variety & Crop cycle & Historical by-product usage \\
\hline 1 & Pereira Barreto - SP & $20^{\circ} 43^{\prime} \mathrm{S}-51^{\circ} 07^{\prime} \mathrm{W}, 350 \mathrm{~m}$ alt. & SP81-3250 & $1^{\text {st }}$ ratoon & None \\
2 & Tabapuã $-\mathrm{SP}$ & $20^{\circ} 58^{\prime} \mathrm{S}-49^{\circ} 03^{\prime} \mathrm{W}, 520 \mathrm{~m}$ alt. & RB95 5970 & $3^{\text {rd }}$ ratoon & None \\
3 & Tabapuã $-\mathrm{SP}$ & $20^{\circ} 57^{\prime} \mathrm{S}-49^{\circ} 03^{\prime} \mathrm{W}, 510 \mathrm{~m}$ alt. & RB95 5970 & $3^{\text {rd }}$ ratoon & Vinasse \\
\hline
\end{tabular}

Table 2 - Soil chemical and physical propertiesa.

\begin{tabular}{|c|c|c|c|c|c|c|c|c|c|c|c|c|c|c|c|c|c|c|}
\hline \multirow{2}{*}{$\begin{array}{l}\text { Sampling } \\
\text { depth }\end{array}$} & \multicolumn{2}{|c|}{$\mathrm{pH}$} & \multirow{2}{*}{ SOC } & \multirow{2}{*}{ Total N } & \multirow{2}{*}{$P$} & \multicolumn{5}{|c|}{ Exchangeable cation(s) } & \multirow{2}{*}{ SB } & \multirow{2}{*}{ CEC } & \multirow{2}{*}{ BS } & \multirow{2}{*}{ AIS } & \multirow{2}{*}{ Sand } & \multirow[b]{2}{*}{ Silt } & \multirow[b]{2}{*}{ Clay } & \multirow{2}{*}{$\begin{array}{c}\text { Bulk } \\
\text { density }\end{array}$} \\
\hline & $\mathrm{H}_{2} \mathrm{O}$ & $\mathrm{KCl}$ & & & & $\mathrm{K}$ & $\mathrm{Ca}$ & $\mathrm{Mg}$ & $\mathrm{Al}$ & $\mathrm{H}+\mathrm{Al}$ & & & & & & & & \\
\hline $\mathrm{m}$ & & & \multicolumn{3}{|c|}{$-\mathrm{g} \mathrm{kg}^{-1}-\mathrm{mg} \mathrm{kg}^{-1}$} & 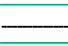 & 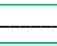 & 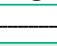 & $\mathrm{nol}_{\mathrm{c}}$ & -1 & 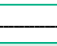 & 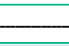 & - & 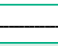 & 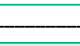 & $\mathrm{g} \mathrm{kg-}$ & 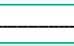 & $\mathrm{Mg} \mathrm{m}^{-3}$ \\
\hline \multicolumn{19}{|c|}{ Site 1} \\
\hline $0.0-0.2$ & 5.6 & 5.2 & 4.9 & 0.88 & 7 & 0.9 & 16 & 8 & 0 & 12 & 24 & 36 & 67 & 0 & 809 & 28 & 163 & - \\
\hline $0.2-0.4$ & 5.0 & 4.3 & 4.4 & 0.83 & 5 & 1.3 & 8 & 7 & 3 & 9 & 15 & 24 & 63 & 17 & 763 & 36 & 201 & - \\
\hline $0.4-0.6$ & 4.8 & 4.1 & 3.6 & 0.63 & 3 & 1.4 & 7 & 6 & 7 & 11 & 13 & 24 & 54 & 35 & 750 & 44 & 206 & - \\
\hline $0.6-0.8$ & 4.5 & 4.1 & 2.7 & 0.64 & 3 & 0.9 & 6 & 4 & 6 & 9 & 10 & 19 & 53 & 38 & 751 & 22 & 226 & - \\
\hline $0.8-1.0$ & 4.4 & 4.1 & 2.6 & 0.74 & 1 & 0.8 & 5 & 4 & 7 & 11 & 9 & 20 & 45 & 44 & 740 & 33 & 226 & - \\
\hline \multicolumn{19}{|c|}{ Site 2} \\
\hline $0.0-0.2$ & 5.9 & 5.0 & 4.3 & 0.80 & 21 & 3.6 & 12 & 4 & 0 & 20 & 16 & 36 & 44 & 0 & 800 & 24 & 176 & 1.65 \\
\hline $0.2-0.4$ & 4.8 & 3.9 & 3.9 & 0.72 & 14 & 2.1 & 24 & 9 & 5 & 20 & 33 & 53 & 62 & 13 & 767 & 32 & 201 & 1.75 \\
\hline $0.4-0.6$ & 5.0 & 4.0 & 2.9 & 0.73 & 6 & 2.9 & 15 & 4 & 4 & 17 & 19 & 36 & 53 & 17 & 694 & 30 & 276 & 1.51 \\
\hline $0.6-0.8$ & 5.1 & 4.3 & 3.3 & 0.74 & 4 & 2.6 & 19 & 5 & 0 & 16 & 24 & 40 & 60 & 0 & 653 & 21 & 326 & 1.39 \\
\hline $0.8-1.0$ & 5.4 & 4.7 & 2.9 & 0.76 & 3 & 2.8 & 24 & 5 & 2 & 14 & 29 & 43 & 67 & 6 & 643 & 31 & 327 & 1.38 \\
\hline \multicolumn{19}{|c|}{ Site 3} \\
\hline $0.0-0.2$ & 6.1 & 5.6 & 4.0 & 0.81 & 76 & 5.6 & 31 & 7 & 0 & 9 & 38 & 47 & 81 & 0 & 824 & 51 & 125 & 1.66 \\
\hline $0.2-0.4$ & 5.3 & 4.5 & 3.6 & 0.80 & 22 & 2.4 & 19 & 5 & 0 & 13 & 24 & 37 & 65 & 0 & 804 & 45 & 150 & 1.71 \\
\hline $0.4-0.6$ & 5.8 & 4.7 & 3.1 & 0.69 & 5 & 2.7 & 26 & 6 & 0 & 12 & 32 & 44 & 73 & 0 & 685 & 39 & 276 & 1.56 \\
\hline $0.6-0.8$ & 5.8 & 5.0 & 2.7 & 0.71 & 3 & 3.5 & 34 & 6 & 0 & 13 & 40 & 53 & 75 & 0 & 609 & 40 & 351 & 1.46 \\
\hline $0.8-1.0$ & 5.9 & 5.1 & 3.2 & 0.76 & 3 & 2.6 & 37 & 7 & 0 & 16 & 44 & 60 & 73 & 0 & 592 & 32 & 377 & 1.45 \\
\hline
\end{tabular}

aSOC = soil organic $\mathrm{C} ; \mathrm{SB}=$ sum of bases; $\mathrm{CEC}=$ cation-exchange capacity; $\mathrm{BS}=$ base saturation; $\mathrm{AlS}=\mathrm{Al}$ saturation. 
four rates of calcium ammonium nitrate (CAN) applied 30 days after harvest [50 (T2), 100 (T3), 150 (T4), and 200 (T5) $\mathrm{kg} \mathrm{N} \mathrm{ha}^{-1}$; ; a single rate (100 $\left.\mathrm{kg} \mathrm{N} \mathrm{ha}^{-1}\right)$ of urea (T6) applied 30 days after harvest; and a single rate $(100 \mathrm{~kg} \mathrm{~N}$ $\mathrm{ha}^{-1}$ ) of $\mathrm{NH}_{4} \mathrm{NO}_{3}$ applied 30 (T7), 60 (T8), or 90 (T9) days after harvest. Treatments 1 to 5 were utilized in evaluating $\mathrm{N}$ fertilizer response; treatments 3,6 , and 7 to compare different $\mathrm{N}$ sources; and treatments 7 to 9 for a study of the effect of application timing. The CAN used was a commercial product (YaraBela CAN-27; Yara International ASA, Oslo, Norway) that contains $270 \mathrm{~g} \mathrm{~N} \mathrm{~kg}^{-1}$ (equally split between $\mathrm{NH}_{4}^{+}$and $\mathrm{NO}_{3}^{-}$), $40 \mathrm{~g} \mathrm{Ca} \mathrm{kg}^{-1}$ (as $\mathrm{CaCO}_{3}$ ), and $20 \mathrm{~g} \mathrm{Mg} \mathrm{kg}^{-1}\left(\mathrm{as} \mathrm{MgCO}_{3}\right)$. Fertilizers were manually applied over the sugarcane straw, $20 \mathrm{~cm}$ away from one side of the row and without incorporation. Following normal fertilizer recommendations to avoid $\mathrm{P}$ or $\mathrm{K}$ deficiency (Spironello et al., 1997), all three fields were amended after the 2012 harvest with $14 \mathrm{~kg} \mathrm{P} \mathrm{ha}{ }^{-1}$ as triple superphosphate, and fields 1 and 2 were also fertilized with $56 \mathrm{~kg} \mathrm{~K} \mathrm{ha}^{-1}$ as $\mathrm{KCl}$. The latter application was not deployed at Site 3, where vinasse application had supplied ample K (199 kg $\mathrm{ha}^{-1}$ ) as well as $22 \mathrm{~kg} \mathrm{~N} \mathrm{ha}^{-1}, 1.4 \mathrm{~kg} \mathrm{P} \mathrm{ha}^{-1}$, and $38 \mathrm{~kg} \mathrm{~S}$ $\mathrm{ha}^{-1}$. Growing conditions were monitored for each field site throughout the experimental period, from continuous measurements of precipitation and air temperature, taken by a nearby weather station (Figure 1).

\section{Soil measurements}

Mineral $\mathrm{N}$ analyses were performed on the 15 composite samples collected in conjunction with site

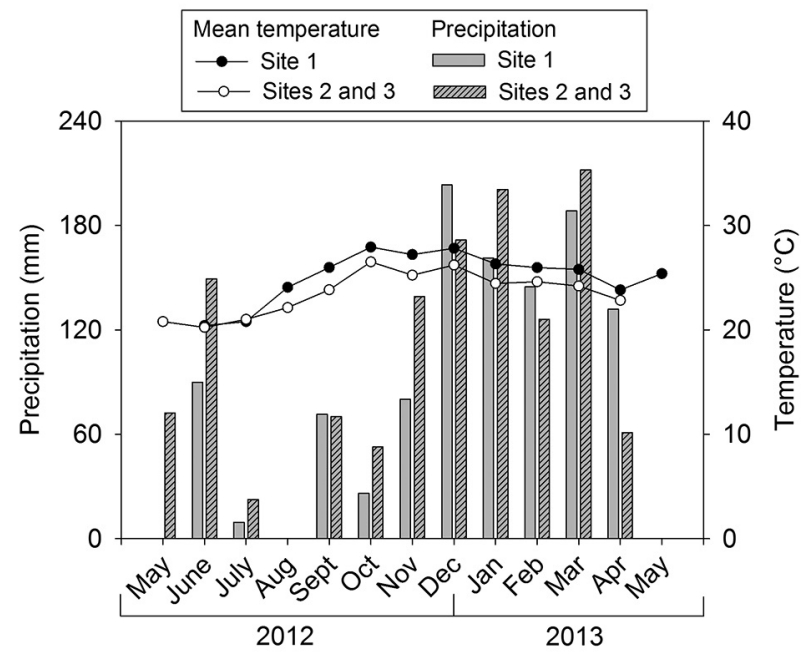

Figure 1 - Monthly precipitation and mean air temperature over the crop cycle at the three field trials. The previous harvest occurred in June 2012 at Site 1, and was followed by fertilizer application in July (30 days after harvest), August (60 days after harvest), and September 2012 (90 days after harvest). Sites 2 and 3 had been previously harvested in May 2012, and were then fertilized in June (30 days after harvest), July (60 days after harvest), and August 2012 (90 days after harvest). Because of their close proximity, aggregated data are shown for Sites 2 and 3. Precipitation totaled $1,106 \mathrm{~mm}$ at Site 1 , while at Sites 2 and 3 reached $1,277 \mathrm{~mm}$. characterization, and subsequently stored in a freezer. After defrosting, triplicate 5-g subsamples (moist weight) were treated with $25 \mathrm{~mL}$ of $2 \mathrm{M} \mathrm{KCl}$ in a $60-\mathrm{mL}$ screwcap polyethylene bottle, and mineral $\mathrm{N}$ was extracted by shaking the resulting suspension for $1 \mathrm{~h}$ on an orbital shaker, followed by filtration through Whatman No. 42 filter paper (GE Healthcare, Buckinghamshire, UK) previously leached with $2 \mathrm{M} \mathrm{KCl}$ to ensure the absence of mineral N. Soil extracts were collected in $125-\mathrm{mL}$ polyethylene bottles that were subsequently stored in a freezer prior to flow-injection analyses using two systems, one equipped for conductivity detection of $\mathrm{NH}_{4}{ }^{+}-\mathrm{N}$ (Reis et al., 1997) and the other for colorimetric determination of $\left(\mathrm{NO}_{3}{ }^{-}+\mathrm{NO}_{2}{ }^{-}\right)-\mathrm{N}$ following $\mathrm{Cd}$ reduction of $\mathrm{NO}_{3}^{-}$to $\mathrm{NO}_{2}^{-}$(Giné et al., 1980). A separate determination was made of soil moisture content by drying a subsample at $105{ }^{\circ} \mathrm{C}$ for $24 \mathrm{~h}$, so as to express inorganic $\mathrm{N}$ concentrations on a dry-weight basis.

Soil samples remaining from the two uppermost depths of 0.0-0.2 and 0.2-0.4 m were utilized in estimating potentially mineralizable $\mathrm{N}$ by the Illinois Soil $\mathrm{N}$ Test (ISNT). For this purpose, the samples were air-dried in a forced-air oven at $40{ }^{\circ} \mathrm{C}$, and then crushed with a mechanical grinder to pass through a $2 \mathrm{~mm}$ screen. ISNT was determined in triplicate according to the procedures described in Khan et al. (2001) and Otto et al. (2013). In preliminary work that involved exhaustive testing of the heating system, $\geq 95 \%$ recovery was obtained according to glucosamine $\mathrm{N}$ standards.

Soil sampling for inorganic $\mathrm{N}$ and the ISNT was repeated after harvesting the trials, in order to estimate temporal changes related to cropping. The post-harvest samples were obtained incrementally as in previous sampling at field establishment, by excavating two holes in each of the check plots (control treatment, T1), approximately $25 \mathrm{~cm}$ from the nearest sugarcane row. The soil thus collected was composited to obtain five samples per site that represented depths of $0-0.2,0.2-0.4$, $0.4-0.6,0.6-0.8$, and 0.8-1.0 m.

\section{Crop measurements}

Sugarcane harvesting took place on May 10, 2013 at Site 1 (first crop cycle) and on April 30, 2013 at S ites 2 and 3 (third crop cycle). To estimate sugarcane yield, the four central rows of each plot were harvested manually without previous burning, by removing dry leaves and tops from the stalks. After harvesting, stalk yield $\left(\mathrm{Mg} \mathrm{ha}^{-1}\right)$ was estimated with a mechanized weighing system, by determining the fresh phytomass cut at ground level. Prior to harvest, ten stalks per plot were randomly collected from the four outside rows for assessment of sugarcane quality by analysis of brix, pol, purity, fiber, and total recoverable sugar. Sugar yield $\left(\mathrm{Mg} \mathrm{ha}^{-1}\right)$ was obtained by multiplying stalk yield $(\mathrm{Mg}$ $\left.\mathrm{ha}^{-1}\right)$ by the corresponding value for pol in juice $\left(\mathrm{g} \mathrm{kg}^{-1}\right)$. Following Dobermann (2005), N use efficiency (NUE), reflecting the uptake of both soil- and fertilizer-derived $\mathrm{N}$, was calculated for each $\mathrm{N}$ treatment as NUE $\left(\mathrm{Mg} \mathrm{kg}^{-1}\right.$ $\mathrm{N})=$ stalk yield $\left(\mathrm{Mg} \mathrm{ha}^{-1}\right) / \mathrm{N}$ rate $\left(\mathrm{kg} \mathrm{ha}^{-1}\right)$. 


\section{Statistical and data analysis}

The data collected were subjected to analysis of variance (ANOVA), and also to post-hoc tests when the $F$ test was significant $(p \leq 0.10)$. Data was divided into two data sets, one involving quantitative data ( $\mathrm{N}$ rates) and the other involving qualitative information (sources of $\mathrm{N}$ and application timings). For fertilizer rates varying from 0 to $200 \mathrm{~kg} \mathrm{~N} \mathrm{ha}^{-1}$ (T1-T5), regression analyses were performed (Webster, 2007) using a linear or quadratic regression model optimized for each data set. Tukey's test was carried out at $p<0.05$ on the other data set (T3, T6, $\mathrm{T} 7, \mathrm{~T} 8$, and T9), to compare mean values for different fertilizer sources and application timings. Tukey's test $(p$ $<0.05$ ) was also utilized to compare field sites in respect of inorganic $\mathrm{N}$ and ISNT data and changes over time.

\section{Results}

\section{Weather conditions}

Precipitation during the field trials was sufficient to ensure that sugarcane growth was not limited by moisture stress, and followed a typical pattern for the southeast region of Brazil that is dry in the winter (JuneSeptember) and humid in the summer (NovemberMarch). This pattern is documented by Figure 1, which shows the only exception occurred in June, when precipitation from three different events totaled $129 \mathrm{~mm}$ for Sites 2 and 3.

Historically, weather conditions are drier and warmer where Site 1 is located, than in the vicinity of Sites 2 and 3. This pattern was apparent in carrying out the field trials reported, since the mean air temperature at Site 1 varied from 23 to $28^{\circ} \mathrm{C}$, somewhat wider than the range for Sites 2 and $3\left(20-27^{\circ} \mathrm{C}\right)$ where precipitation totaled 167 $\mathrm{mm}$ more than that recorded for Site 1 (Figure 1).

\section{Soil inorganic nitrogen}

As shown by Table 3, inorganic $\mathrm{N}$ concentrations varied significantly across the three sites at the time the trial was established in 2012. In the case of exchangeable $\mathrm{NH}_{4}{ }^{+}-\mathrm{N}$, Site 2 showed a higher concentration in the surface layer (0.0-0.2 m) and for the entire profile (0.0-1.0 $\mathrm{m})$, than did Site 1 or 3. A different trend was observed for $\left(\mathrm{NO}_{3}^{-}{ }^{-}+\mathrm{NO}_{2}{ }^{-}\right)-\mathrm{N}$, as Site 1 showed significant enrichment in the subsoil $(0.4-1.0 \mathrm{~m})$ relative to Sites 2 and 3, which led to a parallel finding for total mineral $\mathrm{N}$ recovered as $\mathrm{NH}_{4}^{+}+\mathrm{NO}_{3}^{-}+\mathrm{NO}_{2}^{-}$.

Profile sampling was repeated at sugarcane harvest in 2013, and led to the inorganic $\mathrm{N}$ analyses reported in Table 4. Most were lower than the corresponding data collected from the initial sampling when the field trial was established (Table 3), which led to the net negative changes that usually prevailed when comparing inorganic $\mathrm{N}$ concentrations before and after the cropping cycle studied (Table 5). Such changes were to be expected since soil sampling at harvest time was confined to unfertilized control plots subject to crop $\mathrm{N}$ uptake, and tended to be more intensive for $\left(\mathrm{NO}_{3}^{-}+\mathrm{NO}_{2}{ }^{-}\right)-\mathrm{N}$ than
Table 3 - Soil concentrations of inorganic $\mathrm{N}$ as exchangeable ammonium $\left(\mathrm{NH}_{4}{ }^{+}\right)$, nitrate plus nitrite $\left(\mathrm{NO}_{3}{ }^{-}+\mathrm{NO}_{2}{ }^{-}\right)$, and ammonium plus nitrate plus nitrite $\left(\mathrm{NH}_{4}^{+}+\mathrm{NO}_{3}^{-}+\mathrm{NO}_{2}^{-}\right)$when the field trial was established in $2012^{\mathrm{a}}$.

\begin{tabular}{|c|c|c|c|c|c|c|}
\hline \multirow{2}{*}{ Site } & \multicolumn{5}{|c|}{ Sampling depth (m) } & \multirow{2}{*}{$\begin{array}{r}\text { Average } \\
\text { (0.0-1.0 m }\end{array}$} \\
\hline & $0.0-0.2$ & $0.2-0.4$ & $0.4-0.6$ & $0.6-0.8$ & $0.8-1.0$ & \\
\hline \multicolumn{7}{|c|}{$\mathrm{NH}_{4}^{+}-\mathrm{N}\left(\mathrm{mg} \mathrm{kg}^{-1}\right)$} \\
\hline 1 & $1.9 \mathrm{~b}$ & $0.2 \mathrm{a}$ & 0.1 & $0.4 \mathrm{~b}$ & 0.2 & $0.5 \mathrm{~b}$ \\
\hline 2 & $3.4 \mathrm{a}$ & $1.5 \mathrm{a}$ & 0.2 & $2.0 \mathrm{a}$ & 0.4 & $1.5 \mathrm{a}$ \\
\hline 3 & $1.0 \mathrm{~b}$ & $0.3 a$ & 1.1 & $1.0 \mathrm{ab}$ & 1.1 & $0.9 \mathrm{~b}$ \\
\hline$p$ & $<0.001$ & 0.046 & 0.120 & 0.015 & 0.279 & $<0.001$ \\
\hline $\mathrm{HSD}$ & 1.3 & 1.3 & 1.3 & 1.3 & 1.3 & 0.6 \\
\hline \multicolumn{7}{|c|}{$\left(\mathrm{NO}_{3}^{-}+\mathrm{NO}_{2}^{-}\right)-\mathrm{N}\left(\mathrm{mg} \mathrm{kg}^{-1}\right)$} \\
\hline 1 & 1.1 & 2.0 & $13.7 \mathrm{a}$ & $16.7 \mathrm{a}$ & $34.1 \mathrm{a}$ & $13.5 \mathrm{a}$ \\
\hline 2 & 3.4 & 3.1 & $1.5 \mathrm{~b}$ & $1.4 \mathrm{~b}$ & $1.3 \mathrm{~b}$ & $2.2 \mathrm{~b}$ \\
\hline 3 & 1.6 & 1.0 & $1.2 \mathrm{~b}$ & $1.1 \mathrm{~b}$ & $0.7 \mathrm{~b}$ & $1.1 \mathrm{~b}$ \\
\hline$p$ & 0.119 & 0.197 & $<0.001$ & $<0.001$ & $<0.001$ & $<0.001$ \\
\hline $\mathrm{HSD}$ & 2.9 & 2.9 & 2.9 & 2.9 & 2.9 & 1.3 \\
\hline \multicolumn{7}{|c|}{$\left(\mathrm{NH}_{4}^{+}+\mathrm{NO}_{3}^{-}+\mathrm{NO}_{2}^{-}\right)-\mathrm{N}\left(\mathrm{mg} \mathrm{kg}^{-1}\right)$} \\
\hline 1 & $3.0 \mathrm{~b}$ & $2.2 \mathrm{ab}$ & $13.8 \mathrm{a}$ & $17.0 \mathrm{a}$ & $34.3 \mathrm{a}$ & $14.0 \mathrm{a}$ \\
\hline 2 & $6.8 \mathrm{a}$ & $4.6 \mathrm{a}$ & $1.8 \mathrm{~b}$ & $3.4 \mathrm{~b}$ & $1.8 \mathrm{~b}$ & $3.7 \mathrm{~b}$ \\
\hline 3 & $2.5 \mathrm{~b}$ & $1.3 b$ & $2.3 b$ & $2.1 \mathrm{~b}$ & $1.8 \mathrm{~b}$ & $2.0 \mathrm{c}$ \\
\hline$p$ & 0.003 & 0.033 & $<0.001$ & $<0.001$ & $<0.001$ & $<0.001$ \\
\hline $\mathrm{HSD}$ & 3.1 & 3.1 & 3.1 & 3.1 & 3.1 & 1.4 \\
\hline
\end{tabular}

aalues followed by the same letter in a column do not differ significantly by Tukey's test $(p<0.05) ; \mathrm{HSD}=$ honest significant difference.

Table 4 - Soil concentrations of inorganic $\mathrm{N}$ as exchangeable ammonium $\left(\mathrm{NH}_{4}^{+}\right)$, nitrate plus nitrite $\left(\mathrm{NO}_{3}{ }^{-}+\mathrm{NO}_{2}{ }^{-}\right)$, and ammonium plus nitrate plus nitrite $\left(\mathrm{NH}_{4}^{+}+\mathrm{NO}_{3}^{-}+\mathrm{NO}_{2}^{-}\right)$at harvest in $2013^{\text {a }}$.

\begin{tabular}{|c|c|c|c|c|c|c|}
\hline \multirow{2}{*}{ Site } & \multicolumn{5}{|c|}{ Sampling depth (m) } & \multirow{2}{*}{$\begin{array}{c}\text { Average } \\
(0.0-1.0 \mathrm{~m})\end{array}$} \\
\hline & $0.0-0.2$ & $0.2-0.4$ & $0.4-0.6$ & $0.6-0.8$ & $0.8-1.0$ & \\
\hline \multicolumn{7}{|c|}{$\mathrm{NH}_{4}^{+}-\mathrm{N}\left(\mathrm{mg} \mathrm{kg}^{-1}\right)$} \\
\hline 1 & 1.0 & 0.7 & $0.7 \mathrm{a}$ & $0.7 a$ & 0.3 & $0.7 \mathrm{a}$ \\
\hline 2 & 0.9 & 0.4 & $0.0 \mathrm{~b}$ & $0.0 \mathrm{~b}$ & 0.3 & $0.3 b$ \\
\hline 3 & 1.3 & 0.6 & $0.2 \mathrm{ab}$ & $0.4 \mathrm{ab}$ & 0.1 & $0.5 \mathrm{ab}$ \\
\hline$p$ & 0.129 & 0.236 & 0.007 & 0.002 & 0.353 & 0.002 \\
\hline $\mathrm{HSD}$ & 0.5 & 0.5 & 0.5 & 0.5 & 0.5 & 0.2 \\
\hline \multicolumn{7}{|c|}{$\left(\mathrm{NO}_{3}{ }^{-}+\mathrm{NO}_{2}{ }^{-}\right)-\mathrm{N}\left(\mathrm{mg} \mathrm{kg}^{-1}\right)$} \\
\hline 1 & 0.2 & $0.0 \mathrm{~b}$ & $0.4 \mathrm{a}$ & 0.2 & $0.1 \mathrm{~b}$ & $0.2 \mathrm{~b}$ \\
\hline 2 & 0.0 & $0.3 a$ & $0.1 \mathrm{~b}$ & 0.0 & $0.0 \mathrm{~b}$ & $0.1 \mathrm{~b}$ \\
\hline 3 & 0.0 & $0.0 \mathrm{~b}$ & $0.0 \mathrm{~b}$ & 0.0 & $4.8 \mathrm{a}$ & $1.0 \mathrm{a}$ \\
\hline$p$ & 0.151 & 0.015 & 0.001 & 0.250 & $<0.001$ & $<0.001$ \\
\hline $\mathrm{HSD}$ & 0.3 & 0.3 & 0.3 & 0.3 & 0.3 & 0.1 \\
\hline \multicolumn{7}{|c|}{$\left(\mathrm{NH}_{4}^{+}+\mathrm{NO}_{3}^{-}+\mathrm{NO}_{2}^{-}\right)-\mathrm{N}\left(\mathrm{mg} \mathrm{kg}^{-1}\right)$} \\
\hline 1 & 1.1 & 0.7 & $1.1 \mathrm{a}$ & $0.9 \mathrm{a}$ & $0.4 b$ & $0.8 \mathrm{~b}$ \\
\hline 2 & 1.0 & 0.7 & $0.1 \mathrm{~b}$ & $0.0 \mathrm{~b}$ & $0.3 b$ & $0.4 \mathrm{c}$ \\
\hline 3 & 1.3 & 0.6 & $0.2 b$ & $0.4 a b$ & $4.9 \mathrm{a}$ & $1.5 \mathrm{a}$ \\
\hline$p$ & 0.263 & 0.992 & $<0.001$ & 0.001 & $<0.001$ & $<0.001$ \\
\hline$\underline{\mathrm{HSD}}$ & 0.5 & 0.5 & 0.5 & 0.5 & 0.5 & 0.2 \\
\hline
\end{tabular}

aalues followed by the same letter in a column do not differ significantly by Tukey's test $(p<0.05) ;$ HSD $=$ honest significant difference.

for exchangeable $\mathrm{NH}_{4}{ }^{+}-\mathrm{N}$. When averaged over the depth of sampling, total inorganic $\mathrm{N}$ concentrations at harvest time followed the order, Site $3>$ Site $2>$ Site 1 (Table 4), which reflects inorganic $\mathrm{N}$ decreases that were largest for Site 1 and smallest for Site 3 (Table 5). 


\section{Illinois Soil Nitrogen Test}

Table 6 shows potentially mineralizable $\mathrm{N}$ as estimated by the ISNT for the upper two sampling depths. The data for all three sites show the usual decrease

Table 5 - Net change in soil concentrations of inorganic $\mathrm{N}$ as exchangeable ammonium $\left(\mathrm{NH}_{4}^{+}\right)$, nitrate plus nitrite $\left(\mathrm{NO}_{3}{ }^{-}+\mathrm{NO}_{2}^{-}\right)$, and ammonium plus nitrate plus nitrite $\left(\mathrm{NH}_{4}{ }^{+}+\mathrm{NO}_{3}{ }^{-}+\mathrm{NO}_{2}^{-}\right)$, between field establishment (2012) and harvest (2013).

\begin{tabular}{|c|c|c|c|c|c|c|}
\hline \multirow{2}{*}{ Site } & \multicolumn{5}{|c|}{ Sampling depth (m) } & \multirow{2}{*}{$\begin{array}{c}\text { Average } \\
(0.0-1.0 \mathrm{~m})\end{array}$} \\
\hline & $0.0-0.2$ & $0.2-0.4$ & $0.4-0.6$ & $0.6-0.8$ & $0.8-1.0$ & \\
\hline \multicolumn{7}{|c|}{$\mathrm{NH}_{4}^{+}-\mathrm{N}\left(\mathrm{mg} \mathrm{kg}^{-1}\right)$} \\
\hline 1 & $-0.9 a$ & $0.4 \mathrm{a}$ & $0.6 \mathrm{a}$ & $0.4 \mathrm{a}$ & 0.1 & $0.1 \mathrm{~b}$ \\
\hline 2 & $-2.5 b$ & $-1.1 b$ & $-0.2 a b$ & $-2.0 b$ & -0.1 & $-1.2 \mathrm{a}$ \\
\hline 3 & $0.3 a$ & $0.2 a b$ & $-0.9 b$ & $-0.6 a$ & -1.0 & $-0.4 b$ \\
\hline$p$ & $<0.001$ & 0.019 & 0.048 & 0.001 & 0.156 & $<0.001$ \\
\hline HSD & 1.4 & 1.4 & 1.4 & 1.4 & 1.4 & 0.6 \\
\hline \multicolumn{7}{|c|}{$\left(\mathrm{NO}_{3}{ }^{-}+\mathrm{NO}_{2}^{-}\right)-\mathrm{N}\left(\mathrm{mg} \mathrm{kg}^{-1}\right)$} \\
\hline 1 & -0.9 & -2.0 & $-13.3 b$ & $-16.5 b$ & $-33.9 a$ & $-13.3 c$ \\
\hline 2 & -3.4 & -2.8 & $-1.5 \mathrm{a}$ & $-1.4 \mathrm{a}$ & $-1.3 b$ & $-2.1 b$ \\
\hline 3 & -1.6 & -1.0 & $-1.2 \mathrm{a}$ & -1.1 a & $4.1 \mathrm{a}$ & $-0.1 \mathrm{a}$ \\
\hline$p$ & 0.095 & 0.293 & $<0.001$ & $<0.001$ & $<0.001$ & $<0.001$ \\
\hline HSD & 2.9 & 2.9 & 2.9 & 2.9 & 2.9 & 1.3 \\
\hline \multicolumn{7}{|c|}{$\left(\mathrm{NH}_{4}^{+}+\mathrm{NO}_{3}^{-}+\mathrm{NO}_{2}^{-}\right)-\mathrm{N}\left(\mathrm{mg} \mathrm{kg}^{-1}\right)$} \\
\hline 1 & $-1.8 \mathrm{a}$ & $-1.5 a b$ & $-12.7 b$ & $-16.1 \mathrm{~b}$ & $-33.8 c$ & $-13.2 c$ \\
\hline 2 & $-5.9 b$ & $-4.0 b$ & -1.7 a & $-3.4 a$ & $-1.5 b$ & $-3.3 b$ \\
\hline 3 & $-1.3 \mathrm{a}$ & $-0.7 a$ & $-2.1 \mathrm{a}$ & -1.7 a & $3.1 \mathrm{a}$ & $-0.5 a$ \\
\hline$p$ & $<0.001$ & 0.020 & $<0.001$ & $<0.001$ & $<0.001$ & $<0.001$ \\
\hline $\mathrm{HSD}$ & 2.8 & 2.8 & 2.8 & 2.8 & 2.8 & 1.3 \\
\hline
\end{tabular}

avalues followed by the same letter in a column do not differ significantly by Tukey's test $(p<0.05)$; HSD = honest significant difference.

Table 6 - Potentially mineralizable $\mathrm{N}$ estimated by the Illinois Soil N Test (ISNT) for samples collected when the field trial was established (2012) and harvesting (2013), and ISNT changes over time ${ }^{\mathrm{a}}$.

\begin{tabular}{|c|c|c|c|}
\hline \multirow{2}{*}{ Site } & \multicolumn{2}{|c|}{ Sampling depth (m) } & \multirow{2}{*}{$\begin{array}{l}\text { Average } \\
(0-0.4 \mathrm{~m})\end{array}$} \\
\hline & $0-0.2$ & $0.2-0.4$ & \\
\hline \multicolumn{4}{|c|}{$2012\left(\mathrm{mg} \mathrm{kg}^{-1}\right)$} \\
\hline 1 & $72.5 \mathrm{a}$ & 61.9 & $67.2 \mathrm{a}$ \\
\hline 2 & $59.8 b$ & 57.0 & $58.4 \mathrm{~b}$ \\
\hline 3 & $55.8 b$ & 53.1 & $54.4 \mathrm{~b}$ \\
\hline$p$ & $<0.001$ & 0.064 & $<0.001$ \\
\hline HSD & 8.9 & 8.9 & 6.3 \\
\hline \multicolumn{4}{|c|}{$2013\left(\mathrm{mg} \mathrm{kg}^{-1}\right)$} \\
\hline 1 & $65.1 \mathrm{a}$ & 53.7 & 59.4 a \\
\hline 2 & 56.3 a & 46.7 & $51.5 \mathrm{a}$ \\
\hline 3 & $63.2 \mathrm{a}$ & 56.0 & 59.6 a \\
\hline$p$ & 0.143 & 0.125 & 0.035 \\
\hline HSD & 11.6 & 11.6 & 8.2 \\
\hline \multicolumn{4}{|c|}{ Change between 2012 and $2013\left(\mathrm{mg} \mathrm{kg}^{-1}\right)$} \\
\hline 1 & $-7.5 b$ & -8.2 & $-7.8 b$ \\
\hline 2 & $-3.5 a b$ & -10.3 & $-6.9 b$ \\
\hline 3 & $7.4 \mathrm{a}$ & 2.8 & $5.1 \mathrm{a}$ \\
\hline$p$ & 0.040 & 0.063 & 0.008 \\
\hline HSD & 14.3 & 14.3 & 10.1 \\
\hline
\end{tabular}

avalues followed by the same letter in a column do not differ significantly by Tukey's test $(p<0.05)$; HSD = honest significant difference. with depth, which is consistent with SOC levels that were higher for the plow layer than the subsurface soil (Table 2). This concurrence is also apparent from the finding that ISNT levels when the field trial was established in 2012 were maximized for Site 1 that had a higher SOC content than Site 2 or 3. Cropping lowered ISNT levels for Sites 1 and 2, whereas test values were somewhat higher at harvest time than when the field trial was established for Site 3, where vinasse had been applied.

\section{Sugarcane yield and quality}

With somewhat drier weather (Figure 1) and a different sugarcane variety (Table 1), stalk yield was lower at Site 1 than at Sites 2 and 3. This is documented by Table 7, which shows the same pattern for sugar yield and every quality parameter evaluated, with no significant difference between Sites 2 and 3. This reflects the similarity of growing conditions for two sites in close proximity and planted with the same sugarcane variety.

Table 8 summarizes stalk yield response to rates, sources, and timing of $\mathrm{N}$ fertilization. A significant response was observed for $\mathrm{N}$ rates applied to Sites 1 and 2, whereas yields at Site 3 were unaffected by $\mathrm{N}$ fertilization. A good fit $\left(R^{2}>0.60\right)$ was achieved by modeling yield data from Site 1 with a quadratic response function that predicted a maximum yield of $94 \mathrm{Mg} \mathrm{ha}^{-1}$ with 150 $\mathrm{kg} \mathrm{N} \mathrm{ha}{ }^{-1}$, while the corresponding prediction for Site 2 was $98 \mathrm{Mg} \mathrm{ha}^{-1}$ with $100 \mathrm{~kg} \mathrm{~N} \mathrm{ha}^{-1}$. The two responsive sites differed with respect to $\mathrm{N}$ sources and application timing. At Site $1, \mathrm{NH}_{4} \mathrm{NO}_{3}$ was more effective than CAN for increasing stalk yields, and the best application time was 30 days after harvesting. At Site 2, there was no significant difference in yield response to CAN, urea, or $\mathrm{NH}_{4} \mathrm{NO}_{3}$, and no advantage in making the application 30,60 , or 90 days after harvesting.

\section{Nitrogen use efficiency}

Besides evaluating the $\mathrm{N}$ rate, source, and application timing for their effects on stalk yield, Table 8 presents NUE values calculated to compare these factors for their potential in maximizing the agronomic return from

Table 7 - Sugarcane stalk and sugar yields and quality parametersa.

\begin{tabular}{|c|c|c|c|c|c|c|c|}
\hline Site & $\begin{array}{l}\text { Stalk } \\
\text { yield }\end{array}$ & $\begin{array}{l}\text { Sugar } \\
\text { yield }\end{array}$ & Brix ${ }^{c}$ & Pold $^{d}$ & Fiber & Purity & Pol in ju \\
\hline \multicolumn{8}{|c|}{ Mg ha ${ }^{-1}$} \\
\hline & $90.3 b$ & $11.1 \mathrm{~b}$ & b & b & $10.2 b$ & & \\
\hline & $93.0 \mathrm{a}$ & $13.8 \mathrm{a}$ & a & a & $12.7 \mathrm{a}$ & $a$ & \\
\hline & $95.0 \mathrm{a}$ & $14.0 \mathrm{a}$ & $2 \mathrm{a}$ & $17.7 \mathrm{a}$ & $12.8 \mathrm{a}$ & $87.3 \mathrm{a}$ & a \\
\hline & 0.018 & 0.001 & O & $<0.001$ & $<0.001$ & $<0.001$ & 001 \\
\hline DD & 3.0 & 0.5 & 0.3 & 0.2 & 0.2 & 1.1 & 0.2 \\
\hline
\end{tabular}

aData reported as a mean value for all treatments at each site. Values followed by the same letter within a column do not differ significantly by Tukey's test $(p<0.05)$. HSD = honest significant difference; ${ }^{\circ}$ Calculated as (pol in juice $x$ stalk yield)/100; 'Percentage of total soluble solids as estimated with a refractometer; ${ }^{p}$ Percentage of sucrose as estimated from polarization measured in a saccharimeter. 
Table 8 - Sugarcane stalk yield and $\mathrm{N}$ use efficiency (NUE) as related to $\mathrm{N}$ rates, sources, and timinga.

\begin{tabular}{|c|c|c|c|c|c|c|c|c|c|}
\hline \multirow{2}{*}{ Treatment } & & \multicolumn{4}{|c|}{ Stalk yield $\left(\mathrm{Mg} \mathrm{ha}^{-1}\right)$} & \multicolumn{4}{|c|}{ NUE (Mg kg-1) } \\
\hline & & Site 1 & Site 2 & Site 3 & Mean & Site 1 & Site 2 & Site 3 & Mean \\
\hline \multicolumn{10}{|l|}{$\mathrm{N}$ rate $\left(\mathrm{kg} \mathrm{ha}^{-1}\right)$} \\
\hline 0 & & 83.9 & 84.0 & 93.0 & 87.0 & - & - & - & - \\
\hline 50 & & 85.5 & 87.9 & 94.4 & 89.2 & 1.71 & 1.76 & 1.89 & 1.78 \\
\hline 100 & & 86.1 & 97.8 & 94.0 & 92.6 & 0.86 & 0.98 & 0.94 & 0.93 \\
\hline 150 & & 94.1 & 90.6 & 97.4 & 94.1 & 0.63 & 0.60 & 0.65 & 0.63 \\
\hline 200 & & 89.4 & 90.9 & 90.6 & 90.3 & 0.45 & 0.45 & 0.45 & 0.45 \\
\hline p rates & & 0.025 & 0.003 & 0.350 & 0.004 & $<0.001$ & $<0.001$ & $<0.001$ & $<0.001$ \\
\hline$p$ sites $\times$ rates & & 0.036 & & & & 0.004 & & & \\
\hline$R^{2}(\mathrm{LR})$ & & - & - & - & & 0.86 & 0.90 & 0.87 & 0.88 \\
\hline$R^{2}(\mathrm{QR})$ & & 0.61 & 0.68 & - & 0.87 & 0.98 & 0.99 & 0.99 & 0.99 \\
\hline \multicolumn{10}{|l|}{ Sources and timing } \\
\hline Control & - & $83.9 \mathrm{c}$ & $84.0 \mathrm{~b}$ & 93.0 & $87.0 \mathrm{~b}$ & - & - & - & - \\
\hline CAN & 30 days & $86.1 \mathrm{bc}$ & $97.8 \mathrm{a}$ & 94.0 & $92.6 a b$ & $0.86 \mathrm{~b}$ & 0.98 & 0.94 & 0.93 \\
\hline Urea & 30 days & $93.6 \mathrm{abc}$ & $92.7 \mathrm{ab}$ & 93.7 & $93.3 \mathrm{a}$ & $0.94 a b$ & 0.93 & 0.94 & 0.93 \\
\hline $\mathrm{NH}_{4} \mathrm{NO}_{3}$ & 30 days & 97.9 a & $93.0 \mathrm{ab}$ & 95.7 & $95.5 \mathrm{a}$ & $0.98 a$ & 0.93 & 0.96 & 0.96 \\
\hline $\mathrm{NH}_{4}^{4} \mathrm{NO}_{3}^{3}$ & 60 days & $86.2 b c$ & $95.4 \mathrm{a}$ & 95.4 & $92.3 \mathrm{ab}$ & $0.86 \mathrm{~b}$ & 0.95 & 0.95 & 0.92 \\
\hline $\mathrm{NH}_{4} \mathrm{NO}_{3}$ & 90 days & $94.3 \mathrm{ab}$ & $95.0 \mathrm{a}$ & 97.8 & 95.7 a & $0.94 \mathrm{ab}$ & 0.95 & 0.98 & 0.96 \\
\hline$p$ sources & & 0.002 & 0.015 & 0.844 & 0.003 & 0.017 & 0.676 & 0.828 & 0.441 \\
\hline$p$ sites $\times$ sources & & 0.072 & & & & 0.130 & & & \\
\hline HSD & & 10.3 & 10.3 & 10.3 & 5.9 & 0.11 & 0.11 & 0.11 & 0.07 \\
\hline
\end{tabular}

Values followed by the same letter in a column do not differ significantly by Tukey's test $(p<0.05) ; \mathrm{LR}=$ linear regression; $\mathrm{QR}=$ quadratic regression; CAN $=$ calcium ammonium nitrate $\left(\mathrm{NH}_{4} \mathrm{NO}_{3} \cdot \mathrm{CaCO}_{3}\right) ; \mathrm{HSD}=$ honest significant difference.

$\mathrm{N}$ fertilization. For all three Sites, on average, there was a progressive and highly significant decrease in NUE as the $\mathrm{N}$ rate increased from 50 to $200 \mathrm{~kg} \mathrm{ha}^{-1}$, which was better represented by quadratic than by linear regression. The other two factors were significant only at Site 1 , and in both cases the largest effect was limited to a $14 \%$ increase in NUE that was observed by comparing $\mathrm{NH}_{4} \mathrm{NO}_{3}$ applied 30 days after harvesting with the CAN application made at the same time or with the 60-day $\mathrm{NH}_{4} \mathrm{NO}_{3}$ treatment. On average for all three sites studied, NUE was unaffected by the $\mathrm{N}$ fertilizer source and the time of post-harvest application.

\section{Discussion}

The work carried out was mainly motivated by the growing trend toward application of vinasse to Brazilian sugarcane fields, which represents a substantial source of organic $\mathrm{C}$ that also supplies appreciable $\mathrm{N}$ (Yang et al., 2013), causing microbial proliferation (Santos et al., 2009) that would be expected to intensify soil N cycling (Christofoletti et al., 2013). Surprisingly, Table 3 provides no evidence that mineral $\mathrm{N}$ concentrations were increased by historical usage of vinasse at Site 3, where the most recent application had been made 2 weeks prior to soil sampling when the field trial was established. This disparity is indicative of net $\mathrm{N}$ immobilization previously documented for sugarcane vinasse by Parnaudeau et al. (2008), despite a $\mathrm{C} / \mathrm{N}$ ratio that averaged 2.0 for the material applied in 2012. A transition to net mineralization would no doubt have occurred during the crop cycle, as tropical conditions enhance microbial $\mathrm{C}$ and $\mathrm{N}$ cycling (Six et al., 2002).

Other factors as well as vinasse composition probably confounded the effect of by-product usage on net $\mathrm{N}$ mineralization. For example, Table 2 shows that soil $\mathrm{pH}$ was considerably lower for Sites 2 and 3 than for Site 1. Because of this difference, the hetero- and autotrophic microbiota would have been more active at Site 1, which coincides with the finding that subsoil concentrations of $\left(\mathrm{NO}_{3}{ }^{-}+\mathrm{NO}_{2}{ }^{-}\right)-\mathrm{N}$ were significantly higher for Site 1 than for Sites 2 and 3 (Table 3). This finding is also consistent with the higher contents of SOC and total $\mathrm{N}$ for the upper two sampling depths at Site 1 (Table 2), suggesting the presence of a larger substrate supply for mineralization. The successive application of vinasse prior to trial establishment in Site 3 resulted in increase in soil $\mathrm{pH}$ and higher levels of $\mathrm{P}$ and soluble $\mathrm{Al}$, as compared to Site 2 (Table 2). Rather than reflecting a natural variation in soil properties that would confound a comparison of similar soils at Sites 2 and 3, these changes were brought about by the management practice we sought to evaluate for secondary effects on soil $\mathrm{N}$ supplying power and sugarcane response to $\mathrm{N}$ fertilization.

As shown in Table 3, the three sites differed in profile concentrations of inorganic $\mathrm{N}$ at when the field trial was established, but the differences were much more pronounced for $\left(\mathrm{NO}_{3}{ }^{-}+\mathrm{NO}_{2}{ }^{-}\right)-\mathrm{N}$ than for exchangeable $\mathrm{NH}_{4}{ }^{+}-\mathrm{N}$, which was usually below $2 \mathrm{mg} \mathrm{kg}^{-1}$. Nitrification would have contributed to the low levels of $\mathrm{NH}_{4}{ }^{+} \mathrm{N}$, but more importantly, soil sampling was performed during the dry period in June and July (see Figure 1) when the 
winter season also brings low temperatures to the southeast region of Brazil. These cool, dry conditions represent the main period of sugarcane harvesting and fertilization (Cantarella et al., 2008) but would have limited soil microbial activity, and thus inorganic $\mathrm{N}$ production through mineralization.

Differences between the three sites in $\mathrm{NO}_{3}^{-}+$ $\left.\mathrm{NO}_{2}{ }^{-}\right)-\mathrm{N}$ were confined to the subsoil, and would not have been detected by sampling to a depth of only 0.20 or 0.40 $\mathrm{m}$ (Table 3). For each of the three greater sampling depths (0.60-1.00 m), Site 1 showed significant enrichment of $\left(\mathrm{NO}_{3}{ }^{-}+\mathrm{NO}_{2}{ }^{-}\right)-\mathrm{N}$ which was not observed for Sites 2 and 3. This finding could easily be misinterpreted as evidence that Site 1 was high in soil $\mathrm{N}$ supplying power, when in fact only Site 3 was nonresponsive to $\mathrm{N}$ fertilization (Table 8). Any such interpretation would overlook the confounding effect from lower precipitation at Site 1, which apparently reduced $\mathrm{NO}_{3}{ }^{-}$leaching losses.

Profile concentrations of $\left(\mathrm{NO}_{3}^{-}+\mathrm{NO}_{2}^{-}{ }^{-}-\mathrm{N}\right.$, and also $\left(\mathrm{NH}_{4}^{+}+\mathrm{NO}_{3}^{-}+\mathrm{NO}_{2}^{-}\right)-\mathrm{N}$, were lower at sugarcane harvest time (Table 4) than when the field trial was established (Table 3), the only exception occurring at the greatest sampling depth at Site 3 where yield was unaffected by $\mathrm{N}$ fertilization. The temporal decline is readily apparent from the preponderance of negative values in Table 5, which shows that the net decrease in total inorganic $\mathrm{N}$, when averaged for the entire profile, was significantly greater for Site $1\left(-13.2 \mathrm{mg} \mathrm{kg}^{-1}\right)$ than for Site $2\left(-3.3 \mathrm{mg} \mathrm{kg}^{-1}\right)$ or Site $3\left(-0.5 \mathrm{mg} \mathrm{kg}^{-1}\right)$. The last finding cannot be attributed to a difference in crop $\mathrm{N}$ uptake, as biomass production was lower at Site 1 than at Sites 2 and 3 (Table 7). A more viable explanation is that soil $\mathrm{N}$ supplying power varied across the three sites, such that Site 1 was lowest and Site 3 highest in the potential for net $\mathrm{N}$ mineralization. This view is consistent with evidence that historical application of vinasse enhances the synthesis of soil microbial biomass (Yang et al., 2013).

Although Table 5 suggests that soil N supplying power was related to temporal changes in mineral $\mathrm{N}$ during the period of sugarcane growth, these changes would be of no predictive value for $\mathrm{N}$ fertilizer management because of the need for profile sampling before and after the growing season. A further complication arises from the spatial and temporal dynamics of soil inorganic $\mathrm{N}$, reflecting complex interactions between numerous $\mathrm{N}$ cycle processes (e.g., mineralization, immobilization, nitrification, denitrification, leaching) that are each affected by natural variations in soil temperature and moisture (Mariano et al., 2015). If soil $\mathrm{N}$ testing is to be utilized successfully for improving sugarcane $\mathrm{N}$ management, sampling must be simplified and become a one-time process that takes place in the winter season between fertilization and harvesting. Ideally, testing would be done for a labile organic $\mathrm{N}$ fraction rather than for mineral N, so as to reduce the effects of microbial $\mathrm{N}$ cycling and thereby improve the stability of test values.

The ISNT is suitable in both respects, and has shown potential in recent work by Otto et al. (2013) for differentiating between sites that vary in the responsive- ness of sugarcane to $\mathrm{N}$ fertilization. This potential was not apparent in the present study, as test values prior to when the field trial was established (Table 6) were significantly lower for Sites 2 and 3 than for Site 1, where the highest response was observed for $\mathrm{N}$ fertilizer (Table 8). The implication is that other factors limited soil $\mathrm{N}$ availability and/or sugarcane $\mathrm{N}$ uptake at Site 1 , as would indeed be expected because Table 2 shows that for most if not all sampling depths, this site was lowest in $\mathrm{pH}, \mathrm{P}, \mathrm{K}, \mathrm{Ca}$, and the sum of bases (SB) while being highest in SOC and $\mathrm{Al}$ saturation. The increase in acidity would have impeded soil $\mathrm{N}$ mineralization (Harmsen and van Schreven, 1955), thereby limiting crop utilization of the labile $\mathrm{N}$ fraction estimated by the ISNT. This limitation would have been intensified by the elevated SOC content of the three upper sampling depths at Site 1, which would have promoted immobilization of any mineralized $\mathrm{N}$ produced. Crop $\mathrm{N}$ utilization at this site could also have been reduced if root growth was limited, owing to either Al toxicity associated with high levels of Al saturation or a low subsoil Ca content that becomes important for ratoon crops (Ritchey et al., 1981; Dias et al., 1999). Due in part to their essential roles in supplying adenosine triphosphate (ATP) for $\mathrm{N}$ assimilation (Marschner, 1995), low levels of available $\mathrm{P}$ and $\mathrm{K}$ would have reduced the physiological efficiency of crop $\mathrm{N}$ utilization, thereby increasing yield response to $\mathrm{N}$ fertilization. All of these factors have been significantly correlated with sugarcane productivity (Landell et al., 2003), and the effect in each case would be for the ISNT to overestimate soil $\mathrm{N}$ supplying power. The same effect would have occurred if mineralization was limited by weather conditions which were driest for Site 1 (Figure 1).

Sites 2 and 3 did not differ significantly by the ISNT when sampled and when the field trial was established (Table 6), in contrast to the $\mathrm{N}$ fertilizer response which was most pronounced for Site 2 and totally lacking for Site 3 (Table 8). This disparity illustrates the importance of soil $\mathrm{pH}$ to valid ISNT interpretations, as Table 2 shows that Site 2 was considerably more acidic than Site 3 . Under such conditions, heterotrophic microorganisms would have been less active in carrying out soil $\mathrm{N}$ mineralization, which would increase the fertilizer $\mathrm{N}$ rate needed to optimize productivity. Unfortunately, a higher $\mathrm{N}$ rate will likely increase the acidifying effect of nitrification (Schroder et al., 2011), and thereby lead to further reduction in soil $\mathrm{N}$ availability. Comparison of response data for Sites 2 and 3 (Table 8) demonstrates how soil $\mathrm{N}$ supplying power can be enhanced through the historical usage of vinasse, and suggests that this practice will require a downward shift in ISNT calibration for reliable prediction of fertilizer $\mathrm{N}$ response.

For ISNT measurements at harvest time, no significant differences were detected between the three sites regardless of sampling depth. This is documented by Table 6 , which also shows ISNT changes relative to data collected when the field trial was established. On average, for both depths sampled, Sites 1 and 2 showed a net decrease that differed significantly from the net increase observed 
for Site 3. This finding is consistent with the net changes documented for mineral $\mathrm{N}$ (Table 5), and indicates that Site 3 was higher in soil $\mathrm{N}$ supplying power than Sites 1 and 2, presumably reflecting a buildup of labile $\mathrm{N}$ that resulted from several years of vinasse application.

Such a buildup is confirmed by the response data in Table 8, which shows a significant effect of fertilizer $\mathrm{N}$ rates on stalk yields at Sites 1 and 2, whereas $\mathrm{N}$ fertilization had no effect on sugarcane productivity at Site 3. Positive $\mathrm{N}$ responses by sugarcane are common in the literature (Rossetto et al., 2010; Fortes et al., 2013; Otto et al., 2013; Franco et al., 2015); however, nonresponsive sites have also been reported where there had been a history of by-product usage (Otto et al., 2013). Comparison of Tables 5, 6, and 8 reveals a clear relationship between soil $\mathrm{N}$ availability and the $\mathrm{N}$ fertilizer response, and demonstrates the potential of soil-based $\mathrm{N}$ management to reduce the $\mathrm{N}$ rates without sacrificing productivity, which would necessarily increase NUE.

In addition to comparing stalk yields with different $\mathrm{N}$ rates, the work carried out was designed to ascertain whether sugarcane $\mathrm{N}$ management could be improved by manipulating $\mathrm{N}$ sources or application timing. The results (Table 8 ) show that these strategies were generally ineffective, producing no significant differences where $\mathrm{N}$ response was highest at Site 2 . With respect to $\mathrm{N}$ sources, this finding can be attributed to fertilizer incorporation by a $40 \mathrm{~mm}$ precipitation event that occurred one day after $\mathrm{N}$ application to Sites 2 and 3, which would have prevented $\mathrm{NH}_{3}$ volatilization that can lead to serious $\mathrm{N}$ losses when urea is broadcast-applied over sugarcane straw (Cantarella et al., 2008). Such losses can be safely disregarded in the present study, as yields did not differ between urea and $\mathrm{NH}_{4} \mathrm{NO}_{3}$, an acidic $\mathrm{N}$ source that does not volatilize from acidic soils.

In sugarcane fields harvested early in the season (April-July), Brazilian sugarcane growers normally apply $\mathrm{N}$ fertilizer at the beginning of regrowth, whereas crop $\mathrm{N}$ demand is greatest during the period of maximum dry matter accumulation, which occurs from December through February in southeast Brazil (Franco et al., 2011). As part of the present project, response trials were conducted to compare the fertilizer value of $\mathrm{NH}_{4} \mathrm{NO}_{3}$ applied 30,60 , or 90 days after harvesting, but the results show no consistent advantage for delayed applications (Table 8). One possible explanation is that dry weather conditions during July to September minimized leaching losses of fertilizer-derived $\mathrm{NO}_{3}^{-}$(Ghiberto et al., 2011, 2015). Another is that fertilizer- $\mathrm{N}$ immobilized after application was subsequently mineralized to become available during the summer growth period, providing a source of mineral $\mathrm{N}$ that was not directly dependent on application timing.

The importance of $\mathrm{N}$ rates to sugarcane $\mathrm{N}$ management becomes readily apparent by expressing the $\mathrm{N}$ response in terms of NUE values, which are reported in Table 8 for each site studied and also in terms of an average. A progressive decrease in NUE would be expected from the law of diminishing returns, and in each case this is what was observed. The magnitude of decrease leaves no doubt about the need to avoid excessive $\mathrm{N}$ inputs, which was confirmed by regression analyses that generated the following quadratic functions from site-averaged yield and NUE data: Yield ${ }_{\text {expected }}=-0.0004 \mathrm{~N}_{\text {rate }}{ }^{2}+0.1032 \mathrm{~N}_{\text {rate }}$ $+86.33\left(R^{2}=0.87, p<0.001\right) ; \mathrm{NUE}_{\text {expected }}=0.0007 \mathrm{~N}_{\text {rate }}{ }^{2}$ $-0.0253 \mathrm{~N}_{\text {rate }}+2.8575\left(R^{2}=0.99, p<0.001\right)$. When these functions were used to simulate a $33 \%$ reduction in $\mathrm{N}$ fertilizer rate from which would typically be $120 \mathrm{~kg} \mathrm{ha}^{-1}$, a $54 \%$ increase was predicted for NUE (from 0.83 to 1.28 $\mathrm{Mg}$ stalk kg-1 N) with only $1 \%$ yield loss (from 93 to 92 $\left.\mathrm{Mg} \mathrm{ha}^{-1}\right)$. Such predictions are fully consistent with previous Brazilian sugarcane trials showing 95-98 \% gain in NUE and 1-2 \% yield loss by using 50 rather than $100 \mathrm{~kg}$ $\mathrm{N} \mathrm{ha}^{-1}$ (Otto et al., 2013; Amaral and Molin, 2014).

In contrast to the potential benefits from reducing the $\mathrm{N}$ rate, Table 8 provides little reason to expect that NUE can be increased substantially by changing the $\mathrm{N}$ source or the time of application. This finding must be qualified, however, since the present study was carried out under weather conditions that were not conducive to $\mathrm{NH}_{3}$ volatilization from surface-applied urea.

$\mathrm{N}$ fertilizer rates of at least $100 \mathrm{~kg} \mathrm{ha}^{-1}$ are common for sugarcane in southeast Brazil, and have been widely recommended according to the target yield concept (Spironello et al., 1997). Unfortunately, such recommendations promote excessive fertilization because growers tend to be optimistic about yield goals, while a more fundamental flaw arises from the lack of any means to account for variations in soil $\mathrm{N}$ supplying power. This flaw will become more serious with the growing trend toward by-product usage, as Site 3 demonstrated in our work. There are obvious ramifications for air and water pollution (Erisman et al., 2010; Paredes et al., 2014; Ghiberto et al., 2015) at the producer's expense, while excessive $\mathrm{N}$ also has negative consequences for agricultural productivity by promoting the acidifying effect of nitrification (Schroder et al., 2011) and long-term soil depletion of organic C and N (Khan et al., 2007; Mulvaney et al., 2009). The acidification issue is exacerbated by the limited buffering capacity of tropical soils, and underscores a growing need to improve $\mathrm{N}$ fertilizer recommendations for Brazilian sugarcane production.

Thorburn et al. (2011) suggested a simple alternative to the target yield concept of sugarcane $\mathrm{N}$ management, whereby $\mathrm{N}$ fertilizer is applied at a rate to replace stalk $\mathrm{N}$ removal estimated from average yield data for previous growing seasons. This approach prescribes lower $\mathrm{N}$ fertilizer rates than would normally be recommended by the target yield concept, and thereby leads to an increase in NUE. Unfortunately, no consideration is given to management history, which can have a considerable effect on the responsiveness of sugarcane to $\mathrm{N}$ fertilization (Otto et al., 2013). This could be addressed by incorporating $N$ credits to account for the use of by-products or sugarcane cropping in a legume rotation, as is already being done by several growers who reduce $\mathrm{N}$ rates by 20 to $30 \%$ following the application of vinasse. An even greater reduction would be 
in order, considering the evidence from Otto et al. (2013) and the present study that sites with a history of vinasse usage show limited response, if any, to $\mathrm{N}$ fertilization.

\section{Conclusions}

Sugarcane showed significant yield response to $\mathrm{N}$ fertilization when grown at two sites with no by-product usage, but was nonresponsive at another site having a history of vinasse application. The differences observed in $\mathrm{N}$ fertilizer response were consistent with changes in profile concentrations of mineral $\mathrm{N}$ during the growing season, and the same was true with shallower sampling for potentially mineralizable $\mathrm{N}$ estimated by the ISNT. The latter strategy has more potential than the former for predicting the $\mathrm{N}$ fertilizer requirement from a single sampling prior to fertilization, but test values must be interpreted relative to soil $\mathrm{pH}$ and other factors that affect net $\mathrm{N}$ mineralization or crop $\mathrm{N}$ utilization. Optimizing $\mathrm{N}$ rates for sugarcane production is a far more effective option for increasing NUE than modifying $\mathrm{N}$ sources or application timing, and will become increasingly important with the growing trend toward by-product utilization.

\section{Acknowledgments}

To Fundação de Amparo à Pesquisa do Estado de São Paulo (FAPESP; grant \#2011/22660-7) for providing a scholarship to R. Otto. To Cofco (Catanduva, SP) and Interlagos (Pereira Barreto, SP) bioenergy units for providing field support. R. Otto received a research productivity fellowship from the Conselho Nacional de Desenvolvimento Científico e Tecnológico (CNPq; grant \#308007/2016-6).

\section{Authors' Contributions}

Conceptualization: Otto, R., Trivelin, P.C.O., Mariano, E. Data acquisition: Otto, R., Mariano, E., NastaroBoschiero, B. Data analysis: Otto, R., Mariano, E., Tenelli, S., Boschiero, B.N. Design of Methodology: Otto, R., Trivelin, P.C.O., Mariano, E. Writing and editing: Otto, R., Mariano, E., Trivelin, P.C.O., Tenelli, S., Mulvaney, R.L., Khan, S.A.

\section{References}

Amaral, L.R.; Molin, J.P. 2014. The effectiveness of three vegetation indices obtained from a canopy sensor in identifying sugarcane response to nitrogen. Agronomy Journal 106: 273-280.

Bremner, J.M. 1996. Nitrogen - total. In: Sparks, D.L.; Page, A.L.; Helmke, P.A.; Loeppert, R.H.; Soltanpour, P.N.; Tabatabai, M.A.; Johnston, C.J.; Sumner, M.E., eds. Methods of soil analysis. Part 3. SSSA, Madison, WI, USA.

Bundy, L.G.; Meisinger, J.J. 1994. Nitrogen availability indices. In: Weaver, R.W.; Angle, S.; Bottomley, P.; Bezdicek, D.; Smith, S.; Tabatabai, A.; Wollum, A., eds. Methods of soil analysis. Part 2. SSSA, Madison, WI, USA.
Canellas, L.; Velloso, A.C.X.; Marciano, C.R.; Ramalho, J.F.G.P.; Rumjanek, V.M.; Rezende, C.E.; Santos, G.A. 2003. Chemical soil properties of an Inceptisol under long-term sugarcane crops with vinasse application and without slash burning. Revista Brasileira de Ciência do Solo 37: 935-944 (in Portuguese, with abstract in English).

Cantarella, H.; Trivelin, P.C.O.; Contin, T.L.M.; Dias, F.L.F.; Rossetto, R.; Marcelino, R.; Coimbra, R.B.; Quaggio, J.A. 2008. Ammonia volatilisation from urease inhibitor-treated urea applied to sugarcane trash blankets. Scientia Agricola 65: 397401.

Christofoletti, C.A.; Escher, J.P.; Correia, J.E.; Marinho, J.F.U.; Fontanetti, C.S. 2013. Sugarcane vinasse: environmental implications of its use. Waste Management 33: 2752-2761.

Dias, F.L.F.; Mazza, J.A.; Matsuoka, S.; Perecin, D.; Maule, R.F. 1999. Productivity of sugarcane in relation to climate and soils of the northwestern São Paulo state. Revista Brasileira de Ciência do Solo 23: 627-634 (in Portuguese, with abstract in English).

Dobermann, A.R. 2005. Nitrogen use efficiency: state of the art. University of Nebraska, Lincoln, NE, USA. Available at: http:// digitalcommons.unl.edu/agronomyfacpub/316 [Accessed Sept 09, 2016]

Erisman, J.W.; van Grinsven, H.; Leip, A.; Mosier, A.; Bleeker, A. 2010. Nitrogen and biofuels: an overview of the current state of knowledge. Nutrient Cycling in Agroecosystems 86: 211-223.

Fortes, C.; Trivelin, P.C.O.; Vitti, A.C.; Otto, R.; Franco, H.C.J.; Faroni, C.E. 2013. Stalk and sucrose yield in response to nitrogen fertilization of sugarcane under reduced tillage. Pesquisa Agropecuária Brasileira 48: 88-96.

Franco, H.C.J.; Otto, R.; Faroni, C.E.; Vitti, A.C.; Oliveira, E.C.A.; Trivelin, P.C.O. 2011. Nitrogen in sugarcane derived from fertilizer under Brazilian field conditions. Field Crops Research 121: 29-41.

Franco, H.C.J.; Otto, R.; Vitti, A.C.; Faroni, C.E.; Oliveira, E.C.A.; Fortes, E.C.A.; Ferreira, D.A.; Kolln, O.T.; Garside, A.L.; Trivelin, P.C.O. 2015. Residual recovery and yield performance of nitrogen fertilizer applied at sugarcane planting. Scientia Agricola 72: 528-534.

Gee, G.W.; Or, D. 2002. Particle-size analysis. In: Dane, J.H.; Topp, G.C., eds. Methods of soil analysis. Part 4. SSSA, Madison, WI, USA.

Ghiberto, P.J.; Libardi, P.L.; Brito, A.S.; Trivelin, P.C.O. 2011. Nitrogen fertilizer leaching in an Oxisol cultivated with sugarcane. Scientia Agricola 68: 86-93.

Ghiberto, P.J.; Libardi, P.L.; Trivelin, P.C.O. 2015. Nutrient leaching in an Ultisol cultivated with sugarcane. Agricultural Water Management 31: 141-149.

Giné, M.F.; Bergamin Filho, H.; Zagatto, E.A.G.; Reis, B.F. 1980. Simultaneous determination of nitrate and nitrite by flow injection analysis. Analytica Chimica Acta 114: 191-197.

Grossman, R.B.; Reinsch, T.G.; 2002. Bulk density and linear extensibility. In: Dane, J.H.; Topp, G.C., eds. Methods of soil analysis. Part 4. SSSA, Madison, WI, USA.

Hajaria, E.; Watta, M.P.; Snyman, S. 2013. Towards improved nitrogen use efficiency in sugarcane by overexpression of alanine aminotransferase. South African Journal of Botany 86: 174 . 
Harmsen, G.W.; van Schreven, D.A. 1955. Mineralization of organic nitrogen in soil. Advances in Agronomy 7: 299-398.

Khan, S.A.; Mulvaney, R.L.; Hoeft, R.G. 2001. A simple soil test for detecting sites that are nonresponsive to nitrogen fertilization. Soil Science Society of America Journal 65: 17511760.

Khan, S.A.; Mulvaney, R.L.; Ellsworth, T.R.; Boast, C.W. 2007. The myth of nitrogen fertilization for soil carbon sequestration. Journal of Environmental Quality 36: 1821-1832.

Landell, M.G.A.; Prado, H.; Vasconcelos, A.C.M.; Perecin, D.; Rossetto, R.; Bidoia, M.A.P.; Silva, M.A.; Xavier, M.A. 2003. Oxisol subsurface chemical attributes related to sugarcane productivity. Scientia Agricola 60: 741-745.

Legendre, B.L. 2001. Sugarcane production handbook-2001. Louisiana State University, Baton Rouge, LA, USA. Available at: http://www.lsuagcenter.com/NR/rdonlyres/807E6478-E55644A8-8440-16A2CC4BFD4C/3272/pub2859sugarcane4.PDF [Accessed Nov 04, 2016]

Mariano, E.; Leite, J.M.; Megda, M.X.V.; Tores-Dorante, L.; Trivelin, P.C.O. 2015. Influence of nitrogen form supply on soil mineral nitrogen dynamics, nitrogen uptake and productivity of sugarcane. Agronomy Journal 107: 641-650.

Marschner, H. 1995. Mineral Nutrition of Higher Plants. 2ed. Academic Press, London, England.

Mulvaney, R.L.; Khan, S.A.; Ellsworth, T.R. 2009. Synthetic nitrogen fertilizers deplete soil nitrogen: a global dilemma for sustainable cereal production. Journal of Environmental Quality 38: 1-20.

Nelson, D.W.; Sommers, L.E. 1996. Total carbon, organic carbon, and organic matter. In: Sparks, D.L.; Page, A.L.; Helmke, P.A.; Loeppert, R.H.; Soltanpour, P.N.; Tabatabai, M.A.; Johnston, C.T.; Summer, M.E., eds. Methods of soil analysis. Part 3. Chemical methods. SSSA, Madison, WI, USA.

Otto, R.; Mulvaney, R.L.; Khan, S.A.; Trivelin, P.C.O. 2013. Quantifying soil nitrogen mineralization to improve fertilizer nitrogen management of sugarcane. Biology and Fertility of Soils 49: 893-904.

Paredes, D.S.; Lessa, A.C.R.; Sant'Anna, S.A.C.; Boddey, R.M.; Urquiaga, S.; Alves, B.J.R. 2014. Nitrous oxide emission and ammonia volatilization induced by vinasse and $\mathrm{N}$ fertilizer application in a sugarcane crop at Rio de Janeiro, Brazil. Nutrient Cycling in Agroecosystems 98: 41-55.

Parnaudeau, V.; Condom, N.; Oliver, R.; Cazevieille, P.; Recous, S. 2008. Vinasse organic matter quality and mineralization potential, as influenced by raw material, fermentation and concentration processes. Bioresource Technology 99: 1553-1562.

Raun, W.R.; Johnson, G.V. 1999. Improving nitrogen use efficiency for cereal production. Agronomy Journal 91: 357-363.

Reis, B.F.; Vieira, J.A.; Krug, F.J.; Giné, M.F. 1997. Development of a flow injections system two analytical paths for ammonium determination in soil extracts by conductometry. Journal of Brazilian Chemical Society 8: 523-528.

Ritchey, K.D.; Silva, J.E.; Espinosa, W.; Lobato, E. 1981. Downward movement of calcium and the improvement of subsoil rooting in Oxisols of Brazil. In: Russell, R.S.; Igue, K.; Mehta, Y.R., eds. The soil/root system in relation to Brazilian agriculture. Fundação Instituto Agronômico do Paraná, Londrina, PR, Brazil.
Roberts, T.L.; Norman, R.J.; Fulford, A.M.; Slaton, N.A. 2013. Field validation of N-STaR for rice produced on silt loam soils in Arkansas. Soil Science Society of America Journal 77: 539545.

Rossetto, R.; Dias, F.L.F.; Landell, M.G.A.; Cantarella, H.; Tavares, S.; Vitti, A.C.; Perecin, D. 2010. N and K fertilisation of sugarcane ratoons harvested without burning. Proceedings of the International Society of Sugar Cane Technologist 27: 1-8.

Santos, T.M.C.; Santos, M.A.L.; Santos, C.G.; Santos, V.R. 2009. Effect of fertirrigation with in nature vinasseon the microorganism of the soil. Revista Caatinga 22: 155-160 (in Portuguese, with abstract in English).

Schroeder, B.L.; Wood, A.W.; Moody, P.W.; Panitz, J.H.; Sluggett, R.J.; Salter, B. 2006. Delivering nutrient management guidelines to growers in the central region of the Australian sugar industry. Proceedings of the International Society of Sugar Cane Technologist 28: 142-154.

Schroder, J.L.; Zhang, H.; Girma, G.; Raun, W.R.; Penn, C.J.; Payton, M.E. 2011. Soil acidification from long-term use of nitrogen fertilizers on winter wheat. Soil Science Society of America Journal 75: 957-964.

Silva, F.C.; Abreu, M.F.; Pérez, D.V. 2009. Methods of chemical analysis to evaluate soil fertility $=$ Métodos de análise químicas para avaliação da fertilidade do solo. In: Silva, F.C., ed. Bulletin of chemical analysis of soil, plant, and fertilizers = Manual de análises químicas de solos, plantas e fertilizantes. 2ed. EMBRAPA Informação Tecnológica, Brasília, DF, Brazil (in Portuguese).

Six, J.; Feller, C.; Denef, K.; Ogle, S.; Sa, J.C.M.; Albrecht, A. 2002. Soil organic matter, biota and aggregation in temperate and tropical soils: effects of no-tillage. Agronomie 22: 755-775.

Soil Survey Staff. 2014. Keys to Soil Taxonomy. 12ed. USDANRCS, Washington, DC, USA.

Spironello, A.; Raij, B. van; Penatti, C.P.; Cantarella, H.; Morelli, J.L.; Orlando Filho, J.; Landell, M.G.A.; Rossetto, R. 1997. Other industrial crops = Outras culturas industriais. In: Raij, B. van; Cantarella, H.; Quaggio, J.A.; Furlani, A.M.C., eds. Recommendation of fertilization and liming for the State of São Paulo $=$ Recomendações de adubação e calagem para o estado de São Paulo. 2ed. Instituto Agronômico, Campinas, SP, Brazil. (Boletim Técnico, 100) (in Portuguese).

Thorburn, P.J.; Biggs, J.S.; Webster, A.J.; Biggs, I.M. 2011. An improved way to determine nitrogen fertilizer requirements of sugarcane crops to meet global environmental challenges. Plant and Soil 339: 51-67.

Webster, R. 2007. Analysis of variance, inference, multiple comparisons and sampling effects in soil research. European Journal of Soil Science 58: 74-82.

Whan, A.; Robinson, N.; Lakshmanan, P.; Schmidt, S.; Aitken, K. 2010. A quantitative genetics approach to nitrogen use efficiency in sugarcane. Plant Functional Genetics 37: 448-454.

Yang, S.D.; Liu, J.X.; Wu, J.; Tan, H.W.; Li, Y.R. 2013. Effects of vinasse and press mud application on the biological properties of soils and productivity of sugarcane. Sugar Tech 15: 152-158.

Zhao, D.; Glaz, B.; Comstock, J.C. 2014. Physiological and growth responses of sugarcane genotypes to nitrogen rate on a sand soil. Journal of Agronomy and Crop Science 200: 290-301. 